\title{
Effects of drought on nitrogen turnover and abundances of ammonia-oxidizers in mountain grassland
}

\author{
L. Fuchslueger ${ }^{1, *}$, E.-M. Kastl ${ }^{2, *}$, F. Bauer ${ }^{2,3}$, S. Kienzl ${ }^{1}$, R. Hasibeder ${ }^{4}$, T. Ladreiter-Knauss ${ }^{4}$, M. Schmitt ${ }^{4,5}$, \\ M. Bahn ${ }^{4}$, M. Schloter ${ }^{2}$, A. Richter ${ }^{1}$, and U. Szukics ${ }^{4}$ \\ ${ }^{1}$ Terrestrial Ecosystem Research, Department of Microbiology and Ecosystem Science, University of Vienna, Vienna, Austria \\ ${ }^{2}$ Research Unit Environmental Genomics, Helmholtz Zentrum München, Neuherberg, Germany \\ ${ }^{3}$ Limnologische Station Iffeldorf, Technical University Munich, Munich, Germany \\ ${ }^{4}$ Institute of Ecology, University of Innsbruck, Innsbruck, Austria \\ ${ }^{5}$ Karlsruhe Institute of Technology, Institute or Meteorology and Climate Research, Garmisch-Partenkirchen, Germany \\ *These authors contributed equally to this work.
}

Correspondence to: L. Fuchslueger (lucia.fuchslueger@univie.ac.at) and E.-M. Kastl

(eva-maria.kastl@helmholtz-muenchen.de)

Received: 13 March 2014 - Published in Biogeosciences Discuss.: 17 June 2014

Revised: 17 September 2014 - Accepted: 29 September 2014 - Published: 5 November 2014

\begin{abstract}
Future climate scenarios suggest an increased frequency of summer drought periods in the European Alpine Region. Drought can affect soil nitrogen (N) cycling, by altering $\mathrm{N}$ transformation rates, as well as the abundances of ammonia-oxidizing bacteria and archaea. However, the extent to which drought affects $\mathrm{N}$ cycling under in situ conditions is still controversial. The goal of this study was to analyse effects of drought on soil $\mathrm{N}$ turnover and ammoniaoxidizer abundances in soil without drought history. To this end we conducted rain-exclusion experiments at two differently managed mountain grassland sites, an annually mown and occasionally fertilized meadow and an abandoned grassland. Soils were sampled before, during and after drought and were analysed for potential gross rates of $\mathrm{N}$ mineralization, microbial uptake of inorganic $\mathrm{N}$, nitrification, and the abundances of bacterial and archaeal ammonia-oxidizers based on gene copy numbers of the amoA gene (AOB and AOA, respectively).

Drought induced different responses at the two studied sites. At the managed meadow drought increased $\mathrm{NH}_{4}^{+}$immobilization rates and $\mathrm{NH}_{4}^{+}$concentrations in the soil water solution, but led to a reduction of AOA abundance compared to controls. At the abandoned site gross nitrification and $\mathrm{NO}_{3}^{-}$immobilization rates decreased during drought, while AOB and AOA abundances remained stable. Rewetting had only minor, short-term effects on the parameters
\end{abstract}

that had been affected by drought. Seven weeks after the end of drought no differences to control plots could be detected. Thus, our findings demonstrated that in mountain grasslands drought had distinct transient effects on soil nitrogen cycling and ammonia-oxidizers, which could have been related to a niche differentiation of AOB and AOA with increasing $\mathrm{NH}_{4}^{+}$ levels. However, the effect strength of drought was modulated by grassland management.

\section{Introduction}

Soil water availability is a key factor for physiological processes determining plant productivity and the activity of soil microorganisms (Knapp et al., 2002; Moyano et al., 2013; Stark and Firestone, 1995). Increasing frequencies of drought periods and heavy rainfall events, as predicted for the European Alpine Regions (Gobiet et al., 2014; IPCC, 2007, 2012; Schär et al., 2004; Seneviratne et al., 2006), will lead to strong soil water imbalances and can therefore affect ecosystem nutrient cycling, such as the nitrogen $(\mathrm{N})$ turnover in the soil. Nitrogen is the major growth-limiting nutrient in most non-fertilized terrestrial ecosystems (LeBauer and Treseder, 2008), and its turnover in soils is mainly controlled by microbial processing, such as fixation of atmospheric $\mathrm{N}$, decomposition of organic $\mathrm{N}$ sources, as well as uptake and release of 
ammonium $\left(\mathrm{NH}_{4}^{+}\right)$and nitrate $\left(\mathrm{NO}_{3}^{-}\right)$during mineralization and nitrification processes (Booth et al., 2005; Schimel and Bennett, 2004). These individual steps in soil N cycling occur on different temporal and spatial scales (Schimel and Bennet, 2004) and have been shown to strongly differ in their response, both direction and magnitude, to drought (e.g. Auyeung et al., 2012; Chen et al., 2011; Emmett et al., 2004; Gleeson et al., 2010; Stark and Firestone, 1996).

Nitrogen mineralization and microbial immobilization of $\mathrm{NH}_{4}^{+}$and $\mathrm{NO}_{3}^{-}$can be termed as "broad" processes combining multiple distinct pathways performed by a wide range of microorganisms covering a large spectrum of ecophysiological optima (Schimel and Schaeffer, 2012). "Broad" processes could therefore be more stable to drought than "narrow" ones, such as nitrification (Allison and Martiny, 2008; Schimel and Schaeffer, 2012). Nitrification, the oxidation of ammonia $\left(\mathrm{NH}_{3}\right)$ via nitrite $\left(\mathrm{NO}_{2}^{-}\right)$to nitrate $\left(\mathrm{NO}_{3}^{-}\right)$, has long been expected to be solely performed by a highly specialized group of autotrophic bacteria (Kowalchuk and Stephen, 2001; Schimel et al., 1989), but also archaea of the phylum thaumarchaeota conduct the first step of nitrification, the conversion of $\mathrm{NH}_{3}$ to hydroxylamine $\left(\mathrm{NH}_{2} \mathrm{OH}\right)$ (Könneke et al., 2005). This step is catalyzed by the enzyme ammonia-monooxigenase (AMO), of which the subunit A (amoA) is highly conserved encoded in ammonia-oxidizing bacteria (AOB) and archaea (AOA) (Treusch et al., 2005). Although both AOB and AOA can contribute to ammoniaoxidation, it is unclear to what extent (Prosser and Nicol, 2012) they can be considered as potentially, functionally redundant (Leininger et al., 2006; Schauss et al., 2009). They have however been shown to differ in physiology and ecology (Erguder et al., 2009). In many soils archaeal amoA genes are more abundant than their bacterial counterparts (Alves et al., 2013; Leininger et al., 2006; Prosser and Nicol, 2008), but AOB seem to outcompete AOA and dominate nitrification in agricultural soils (Jia and Conrad, 2009), Nrich grasslands (Di et al., 2009), and at high levels of $\mathrm{NH}_{4}^{+}$ (Brankatschk et al., 2010; Di et al., 2010; Verhamme et al., 2011). Archaeal AMO, in turn, appears to have a higher affinity, and lower inhibition constant for ammonia (MartensHabbena et al., 2009; Prosser and Nicol, 2012), which could be advantageous at low ammonia concentrations.

Whereas the dynamics of $\mathrm{AOB}$ and $\mathrm{AOA}$ to ammonia are well studied, much less is known about responses of ammonia-oxidizers, specifically of AOA, to drought and rewetting under in situ conditions. Generally, AOB and AOA feature different physiological prerequisites (Schauss et al., 2009), presumably also leading to different responses of AOB and AOA to soil drying and rewetting. During drought periods nutrient concentrations in the soil solution increase, forcing microbes to balance the increasing osmotic potential by accumulating or producing osmolytes (Roeßler and Müller, 2001), which could lead to large amounts of $\mathrm{N}$ tied up in the microbial biomass (Schimel et al., 2007). Rainfall events in turn, introduce a water pulse causing a sud- den decrease of the osmotic soil potential; microbes release accumulated osmolytes to avoid lysis (Schimel et al., 2007, Roeßler and Müller, 2001) and are triggered back from low activity or dormant states (Barnard et al., 2013; Placella and Firestone, 2013) resulting in peaks of carbon and $\mathrm{N}$ mineralization (Birch, 1958; Fierer and Schimel, 2002; Evans and Wallenstein, 2012), and of nitrification (Fierer and Schimel, 2002). Thus, both drying and rewetting could lead to high ammonium concentrations in the soil solution which has been shown to adversely affect AOA, but not AOB abundances in non-drought adapted grassland soils, likely related to a niche differentiation of AOB and AOA (Thion and Prosser, 2014).

Most studies on the effects of drought and rewetting on grassland $\mathrm{N}$-cycling and on ammonia-oxidizer abundances originated either from seasonal dry sites (e.g. Fierer and Schimel, 2002; Gleeson et al., 2010; Placella et al., 2013) or from soil mesocosm incubation studies (Thion and Prosser, 2014). However, well water-supplied ecosystems, such as many grasslands in mountainous areas, will be experiencing a higher frequency of drought and heavy rainfall events (Gobiet et al., 2013; IPCC, 2012). These grasslands, which are often in transitions from land-management to abandonment, play a pivotal role in nutrient retention and erosion protection with repercussions on densely populated watersheds downstream. Thus, there is an urgent need study possible effects of such climate extremes on soil $\mathrm{N}$ cycling in situ.

The aim of this study therefore was to investigate effects of drought and subsequent rewetting on gross $\mathrm{N}$ mineralization, gross nitrification, and the abundances of ammonia-oxidizers of mountain meadows under different land-management levels, an extensively managed meadow and an abandoned grassland site in the Austrian Central Alps. At both sites we conducted rain-exclusion experiments to simulate drought and subsequent rewetting, which allowed us to examine the effects of drought in soils with different preconditions, such as soil organic matter content (Meyer et al., 2012), organic and inorganic $\mathrm{N}$ availability (specifically $\mathrm{NH}_{4}^{+}$), and with potentially different abundances of bacterial and archaeal ammonia-oxidizers. We hypothesized that the phylogenetically "broad" process of $\mathrm{N}$ mineralization is less affected by drought than the more "narrow" process of nitrification. We expected AOB and AOA to respond differentially to drought - more specifically, that archaeal amoA abundances would decrease as a consequence of rising ammonium concentrations in the soil solution. Additionally, we hypothesized that the impact of drought on N-turnover and ammonia-oxidizer abundances would be stronger on the managed meadow than on the abandoned site, as the higher soil organic matter content at the abandoned site could act as a buffer against soil drying (Brady and Weil, 2002; Franzluebbers et al., 2002). 
Table 1. Soil parameters, nitrogen pools ( $\mu \mathrm{g} \mathrm{Ng}^{-1} \mathrm{DW}$ soil and in $\mu \mathrm{g} \mathrm{Ng}^{-1}$ soil water: water sol.), nitrogen turnover rates ( $\mu \mathrm{g} \mathrm{N} \mathrm{g}-1$ DW soil $\mathrm{d}^{-1}$ ), mean residence times (MRT) of ammonium and nitrate $(h)$, as well as microbial abundances (gene copies $\mathrm{g}^{-1} \mathrm{DW}$ soil) in soils of the meadow and the abandoned site $(n=28$; means \pm standard error). Effects of site and sampling time, as well as their interaction were assessed by repeated-measures ANOVA for non-drought-treated controls. Asterisks mark levels of significance: ${ }^{\circ}<0.1 ;^{*}=p<0.05 ;^{* *} p<0.01$; ** $p<0.001$ (differences between sites for $\mathrm{WHC}_{\max } ; n=16$, and SOM content $n=12$ were analysed by $t$-tests).

\begin{tabular}{|c|c|c|c|c|c|c|c|c|}
\hline & \multirow{2}{*}{$\begin{array}{r}\text { Meadow } \\
\text { Mean }( \pm S E)\end{array}$} & \multirow{2}{*}{$\begin{array}{l}\text { Abandoned site } \\
\text { Mean }( \pm \text { SE })\end{array}$} & \multicolumn{2}{|c|}{ Site } & \multicolumn{2}{|c|}{ Time } & \multicolumn{2}{|c|}{ Site $\times$ time } \\
\hline & & & $F(1)$ & $p$ & $F(6)$ & $p$ & $F(1,6)$ & $p$ \\
\hline SOM content $(\%)$ & $13.3( \pm 0.8)$ & $22.5( \pm 1.5)$ & & $* * * 1$ & & & & \\
\hline $\mathrm{WHC}_{\max }\left(\mathrm{g} \mathrm{H}_{2} \mathrm{Og}^{-1} \mathrm{DW}\right)$ & $1.5( \pm 0.1)$ & $2.0( \pm 0.3)$ & & $* * * 1$ & & & & \\
\hline $\mathrm{SWC}\left(\%\right.$ of $\left.\mathrm{WHC}_{\max }\right)$ & $44.2( \pm 1.7)$ & $45.4( \pm 1.8)$ & 0.8 & & 5.2 & $* * *$ & 2.6 & $*$ \\
\hline $\mathrm{C}_{\text {tot }}(\%)$ & $7.0( \pm 0.2)$ & $11.2( \pm 0.7)$ & 33.0 & $* * *$ & 1.5 & & 0.9 & \\
\hline $\mathrm{N}_{\text {tot }}(\%)$ & $0.7( \pm 0.1)$ & $0.9( \pm 0.1)$ & 15.2 & $* * *$ & 1.3 & & 0.8 & \\
\hline $\mathrm{C}_{\text {tot }}: \mathrm{N}_{\text {tot }}$ & $10.1( \pm 0.1)$ & $12.0( \pm 0.2)$ & 73.7 & $* * *$ & 1.3 & & 0.2 & \\
\hline$\delta^{13} \mathrm{C}(\% \circ)$ bulk soil & $-26.5( \pm 0.2)$ & $-25.6( \pm 0.1)$ & 44.1 & $* * *$ & 0.9 & & 1.4 & \\
\hline$\delta^{15} \mathrm{~N}(\% \circ)$ bulk soil & $4.9( \pm 0.2)$ & $4.1( \pm 0.2)$ & 11.2 & $* *$ & 1.4 & & 0.9 & \\
\hline EON & $31.4( \pm 1.5)$ & $55.6( \pm 5.5)$ & 33.5 & $* * *$ & 2.1 & & 2.9 & $*$ \\
\hline $\mathrm{NH}_{4}^{+}$ & $5.7( \pm 0.6)$ & $11.1( \pm 0.9)$ & 42.7 & $* * *$ & 2.1 & & 2.8 & $*$ \\
\hline $\mathrm{NO}_{3}^{-}$ & $2.2( \pm 0.6)$ & $0.4( \pm 0.1)$ & 14.2 & $* * *$ & 1.1 & & 3.6 & ** \\
\hline $\mathrm{MRT}_{\mathrm{NH}_{4}}^{+}$ & $27.4( \pm 6.8)$ & $33.3( \pm 6.1)$ & 1.7 & & 2.2 & $\circ$ & 1.3 & \\
\hline $\mathrm{MRT}_{\mathrm{NO}_{3}}^{-}$ & $30.3( \pm 10.0)$ & $2.2( \pm 0.7)$ & 29.4 & $* * *$ & 1.8 & & 2.5 & $*$ \\
\hline EON water sol. & $51.3( \pm 3.4)$ & $60.6( \pm 4.6)$ & 3.8 & $\circ$ & 3.9 & $*$ & 2.5 & $*$ \\
\hline $\mathrm{NH}_{4}^{+}$water sol & $9.2( \pm 0.8)$ & $12.0( \pm 0.7)$ & 12.0 & $* *$ & 2.3 & $\circ$ & 2.0 & $\circ$ \\
\hline $\mathrm{NO}_{3}^{-}$water sol & $3.3( \pm 0.9)$ & $0.5( \pm 0.1)$ & 20.1 & $* * *$ & 0.7 & & 4.0 & $* *$ \\
\hline Gross N Min & $8.5( \pm 1.0)$ & $11.1( \pm 2.0)$ & 0.1 & & 0.9 & & 1.4 & \\
\hline Gross $\mathrm{NH}_{4}^{+}$Immo & $8.1( \pm 0.8)$ & $13.4( \pm 1.7)$ & 1.1 & & 0.5 & & 1.4 & \\
\hline GrossNit & $5.9( \pm 0.7)$ & $11.1( \pm 1.4)$ & 12.4 & $* *$ & 2.9 & $*$ & 1.7 & \\
\hline Gross $\mathrm{NO}_{3}^{-}$Immo & $4.6( \pm 0.9)$ & $12.4( \pm 1.1)$ & 47.4 & $* * *$ & 4.7 & $* * *$ & 2.9 & \\
\hline $\mathrm{AOA}$ & $1.79 \times 10^{6}$ & $1.82 \times 10^{6}$ & 0.0 & & 0.5 & & 0.5 & \\
\hline $\mathrm{AOB}$ & $8.68 \times 10^{5}$ & $2.25 \times 10^{5}$ & 37.2 & $* * *$ & 1.3 & & 0.4 & \\
\hline $\mathrm{AOA}: \mathrm{AOB}$ ratio & $2.8( \pm 0.6)$ & $26.3( \pm 13.2)$ & 27.0 & $* * *$ & 0.4 & & 0.7 & \\
\hline
\end{tabular}

\section{Material and methods}

\subsection{Study sites}

The two studied grasslands are located in the Austrian Central Alps near Neustift, Stubai Valley $\left(47^{\circ} 07^{\prime} \mathrm{N}, 11^{\circ} 19^{\prime} \mathrm{E}\right)$ and are characterized by a mean annual temperature of $3^{\circ} \mathrm{C}$ and a mean annual precipitation of about $1100 \mathrm{~mm}$. Drought simulations were conducted on a typical extensively managed mountain meadow (to be referred to as "meadow", $1850 \mathrm{~m}$ a.s.l.) and on an abandoned meadow site (to be referred to as "abandoned site" $1900 \mathrm{~m}$ a.s.l.). At both sites, soils were characterized as dystric cambisols (FAO classification) with a $\mathrm{pH}$ in the uppermost $10 \mathrm{~cm}$ soil depth of 5.5 (determined in $\mathrm{CaCl}_{2}$ ). At the meadow total aboveground plant biomass is cut and harvested once a year; parts of the meadow are slightly grazed by cattle in spring and autumn, and fertilized with manure every two to three years (Bahn et al., 2006). The meadow is characterized by high plant primary production (Schmitt et al., 2010), by higher soil respiration rates (Bahn et al., 2008), as well as by lower soil organic matter $(\mathrm{SOM})$, total carbon $\left(\mathrm{C}_{\text {tot }}\right)$ and nitrogen $\left(\mathrm{N}_{\text {tot }}\right)$ con- tents compared to the abandoned site (Table 1, and Meyer et al., 2012). At the abandoned site all management activities were terminated in 1983 . The dominant plant community was determined as Trisetetum flavescentis at the meadow, and as Seslerio-Cariecetum at the abandoned site (Schmitt et al., 2010).

\subsection{Experimental set-up and soil sampling}

At both the meadow and the abandoned site, four drought and corresponding control plots were established in spring 2011 in a paired plot design. Drought was simulated by installing rain-out shelters, covering an area of $3.0 \times 3.5 \mathrm{~m}$, for 10 weeks starting on 31 May 2011. The shelters were equipped with light- and UV-B-permeable plastic foil (UV-B Window, Foiltec GmbH, Germany, light-permeability ca. $95 \%$, UV-B permeability $>70 \%$ ) to exclude any precipitation. To maintain the traditional land-management, the total area of the meadow was mown (i.e. aboveground biomass was cut and removed) during the drought period (2 August 2011), while there was no land-management activity at the abandoned site. After 10 weeks of drought (10 August 2011) all plots 


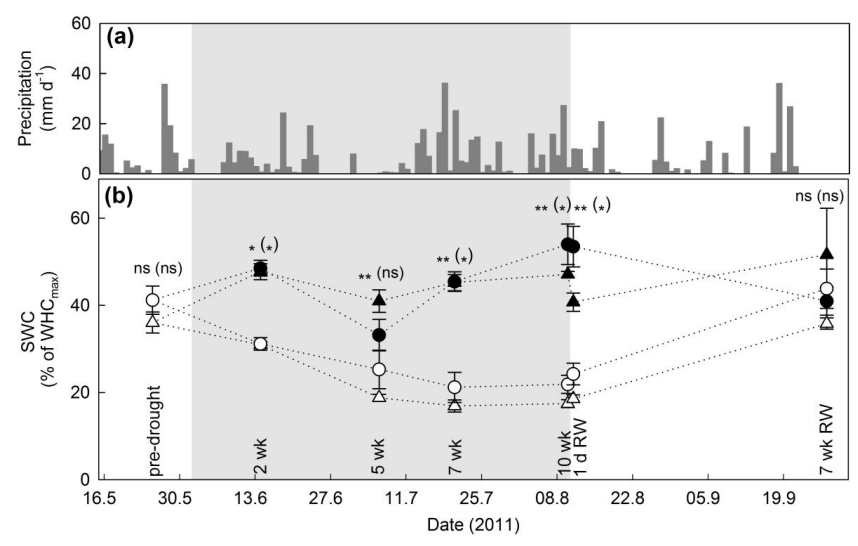

Figure 1. Precipitation (a) and soil water content (b, SWC) calculated as percentage of the respective $\mathrm{WHC}_{\max }$. Grey bars indicate precipitation (in $\mathrm{mm} \mathrm{d}^{-1}$ ). Filled symbols represent controls of the meadow (triangles) and abandoned site (circles), open symbols show the respective drought-treated plots (error bars indicate standard error, $n=4)$. Asterisks indicate differences between controls and drought treatments at single sampling points (levels of significance Bonferroni-corrected; ns, not significant; * $p<0.05$; ** $p<0.01$, symbols without parentheses refer to the meadow; symbols in parentheses to the abandoned site). The period of drought treatment is marked as grey background.

received previously collected rainwater over a time period of 3 min to simulate a short heavy rainfall event of $20 \mathrm{~mm}$; subsequently rain-out shelters were removed and all plots were again exposed to natural precipitation.

Soils were sampled 1 week before the onset of drought simulation, then every 2 to 3 weeks during drought, 1 day and 7 weeks after rewetting (Fig. 1). For each sample two soil collars $(5 \times 7 \mathrm{~cm}, 10 \mathrm{~cm}$ depth) were pooled after the uppermost litter layer had been removed. Then soil collars were homogenized and sieved to $2 \mathrm{~mm}$. Aliquots of soil were immediately frozen at $-80^{\circ} \mathrm{C}$ for molecular analyses; the remaining samples were stored at $4{ }^{\circ} \mathrm{C}$ until further processing.

\subsection{Soil parameters and $\mathrm{N}$ pools}

For both sites maximum soil water holding capacity $\left(\mathrm{WHC}_{\max }\right)$ was determined by adding excess amounts of deionized water to aliquots of soil samples and leaving them for $48 \mathrm{~h}$ over water to allow maximum saturation. Then $2 \mathrm{~g}$ of water-saturated soils were dried for $48 \mathrm{~h}$ at $60^{\circ} \mathrm{C}$. Soil water content (SWC) was measured gravimetrically by drying of $5 \mathrm{~g}$ of fresh soil for two days at $60^{\circ} \mathrm{C}$ in a drying oven and calculated relative to $\mathrm{WHC}_{\max }$. Total carbon $\left(\mathrm{C}_{\text {tot }}\right)$ and $\mathrm{N}\left(\mathrm{N}_{\text {tot }}\right)$ content were determined from dried and ground soil samples by EA-IRMS (EA 1110, CE Instruments, Italy, coupled to a Finnigan MAT Delta Plus IRMS, Thermo Fisher Scientific, MA, USA). Total extractable N was determined from $\mathrm{K}_{2} \mathrm{SO}_{4}$ extracts $(2 \mathrm{~g}$ of soil were extracted with $20 \mathrm{~mL} 0.5 \mathrm{M} \mathrm{K}_{2} \mathrm{SO}_{4}$ ) using a TOC/TN anal- yser (TOC-V CPH E200V/TNM-122V; Shimadzu, Austria). $\mathrm{NH}_{4}^{+}$was measured photometrically from $\mathrm{K}_{2} \mathrm{SO}_{4}$ extracts using a modified indophenol reaction method (Kandeler and Gerber, 1988). $\mathrm{NO}_{3}^{-}$was determined from water extracts ( $2 \mathrm{~g}$ of fresh soil were extracted with $20 \mathrm{~mL}$ of MilliQ water) by chemically suppressed ion-chromatography (DX500, Dionex, Austria) on a Dionex AS11 column. Extractable organic nitrogen (EON) was calculated by subtracting inorganic $\left(\mathrm{NH}_{4}^{+}\right.$and $\left.\mathrm{NO}_{3}^{-}\right)$from total extractable $\mathrm{N}$.

\subsection{Potential gross $\mathbf{N}$ transformation rates}

Potential gross $\mathrm{NH}_{4}^{+}$and $\mathrm{NO}_{3}^{-}$transformation rates were determined using ${ }^{15} \mathrm{~N}$ pool dilution techniques described by Kaiser et al. (2011). For determination of microbial gross $\mathrm{N}$ mineralization and $\mathrm{NH}_{4}^{+}$immobilization, fresh aliquots of soil (2 $\mathrm{g}$ in duplicates) received $0.5 \mathrm{~mL}\left(\mathrm{NH}_{4}\right)_{2} \mathrm{SO}_{4}$ $\left(0.125 \mathrm{mM} ; 10\right.$ atom $\left.\%{ }^{15} \mathrm{~N}\right)$. For determination of gross nitrification and microbial $\mathrm{NO}_{3}^{-}$uptake $\left(\mathrm{NO}_{3}^{-}\right.$immobilization), $2 \mathrm{~g}$ of fresh soil samples (in duplicates) received $0.5 \mathrm{~mL}$ $\mathrm{KNO}_{3}\left(0.25 \mathrm{mM}, 10\right.$ atom $\left.\%{ }^{15} \mathrm{~N}\right)$. Labelled samples were incubated for 4 and $24 \mathrm{~h}$ at room temperature and finally extracted with $20 \mathrm{~mL} 2 \mathrm{M} \mathrm{KCl}$. Both control and droughttreated soils received solute ${ }^{15} \mathrm{~N}$ label, which could have altered the conditions, specifically in drought treated soils (Chen et al., 2011). Therefore, the reported rates should be considered as the $\mathrm{N}$-turnover potential of the soil microbial community.

Potential gross $\mathrm{N}$ mineralization and $\mathrm{NH}_{4}^{+}$immobilization rates were determined by microdiffusion of $\mathrm{NH}_{3}$ from $\mathrm{KCl}-$ extracts into acid traps, which were analysed for nitrogen concentrations and atom-percent excess of ${ }^{15} \mathrm{~N}$ by EA-IRMS (EA 1110, CE Instruments, Italy, coupled to a Finnigan MAT Delta Plus IRMS, Thermo Fisher Scientific, MA, USA). For potential gross nitrification and $\mathrm{NO}_{3}^{-}$immobilization rates $\mathrm{NH}_{3}$ was removed from the extracts, before converting $\mathrm{NO}_{3}^{-}$ to $\mathrm{NH}_{3}$ by adding Devarda's Alloy. Again, $\mathrm{NH}_{3}$ was trapped and analysed for $\mathrm{N}$ concentration and atom-percent excess of ${ }^{15} \mathrm{~N}$. Potential gross $\mathrm{N}$ mineralization, gross $\mathrm{NH}_{4}^{+}$immobilization, as well as potential gross nitrification and gross $\mathrm{NO}_{3}^{-}$immobilization rates were calculated as described in detail by Wanek et al. (2010).

\subsection{Nucleic acid extraction}

DNA was extracted from $0.35 \mathrm{~g}$ of soil using the FastDNA ${ }^{\circledR}$ SPIN Kit for Soil (MP Biomedicals, CA, USA) and the Precellys24 Instrument (Bertin Technologies, France). After extraction, the DNA was tested in quantity and quality with a spectrophotometer (Nanodrop, PeqLab, Germany) and stored at $-20^{\circ} \mathrm{C}$ until further processing.

\subsection{Quantitative Real-Time PCR}

The abundances of the bacterial and archaeal ammoniamonooxygenase gene (amoA) served as proxy for 
Table 2. Thermal profiles and primers used for real-time PCR quantification of functional genes of ammonia-oxidation.

\begin{tabular}{|c|c|c|c|c|}
\hline Target gene & Thermal profile & No. of cycles & Primer & Source of standard \\
\hline amoA AOA & $\begin{array}{l}95^{\circ} \mathrm{C}-10 \min 94^{\circ} \mathrm{C}-45 \mathrm{~s} / \\
55^{\circ} \mathrm{C}-45 \mathrm{~s} / 72^{\circ} \mathrm{C}-45 \mathrm{~s}\end{array}$ & 40 & $\begin{array}{l}\text { amo19F, CrenamoA16r48x } \\
\text { Leininger et al. (2006), Schauss et al. (2009) }\end{array}$ & Fosmid clone $54 \mathrm{~d} 9$ \\
\hline amoA $\mathrm{AOB}$ & $\begin{array}{l}95^{\circ} \mathrm{C}-10 \min 94^{\circ} \mathrm{C}-60 \mathrm{~s} / \\
58^{\circ} \mathrm{C}-60 \mathrm{~s} / 72^{\circ} \mathrm{C}-60 \mathrm{~s}\end{array}$ & 40 & amoA1F, amoA2R Rotthauwe et al. (1997) & Nitrosomonas sp. \\
\hline
\end{tabular}

ammonia-oxidizers and were detected by quantitative Real-Time PCR, which was carried out on a 7300 Real-Time PCR System (Applied Biosystems, Germany) using SYBR green as fluorescent dye. The PCR was performed in 96-well plates (Applied Biosystems, Germany) for all investigated genes. The reaction mixes were performed according to Töwe et al. (2010); the thermal profiles of the PCRs are given in Table 2. In a preliminary test dilution series of the DNA extracts were tested to avoid inhibition of PCR, resulting in an optimal dilution of $1: 128$ for all samples (2-5 ng DNA $\mu \mathrm{L}^{-1}$ per sample). Serial plasmid dilutions of the respective functional genes ranging from $10^{6}$ to $10^{1}$ gene copies $\mu \mathrm{L}^{-1}$ were used as standards for the determination of the gene abundances of each sample (Table 2). To confirm the specificity of the amplicons after each PCR run, a melting curve and a $2 \%$ agarose gel stained with ethidium bromide were conducted. The efficiencies (Eff) of the amplification were calculated from the standard curve with the formula Eff $=\left[10^{(-1 / \text { slope })}-1\right] \times 100 \%$ and resulted in the following values: amoA of ammonia-oxidizing archaea (AOA) $83.4 \%$ to $91.8 \%\left(R^{2}=0.997\right)$ and $a m o A$ of ammonia-oxidizing bacteria (AOB) 94.8 to $95.4 \%\left(R^{2}=0.999\right)$.

\subsection{Statistics}

To determine site-specific differences, all available parameters were compared by repeated-measures ANOVA using only the controls of both sites. As we found significant differences between sites, we subsequently tested for effects of drought by comparing control samples from each study site with drought plots over the course of the experiment by repeated-measures ANOVA, using the plot number as withinfactor. To test for differences between drought and control samples at single sampling time points we used paired $t$ tests with Bonferroni-adjusted levels of significance. All data were tested for normality by Shapiro-Wilk test and for homoscedasticity by Levene's test. If data did not meet ANOVA assumptions they were log-transformed or rank-normalized. All data, including SWC, $\mathrm{C}_{\text {tot }}, \mathrm{N}_{\text {tot }}$, all $\mathrm{N}$ pools and potential $\mathrm{N}$-turnover data, as well as ammonia-oxidizer gene abundances were subjected to principal component analyses (PCA), after they were transformed to meet PCA assumptions. To determine differences between sites and drought on the distribution of the samplings along the PC-axes, we conducted a two-way ANOVA. All statistical analyses were performed using R 2.15.2 (R Core Team, 2012).

\section{Results}

\subsection{Effects of drought on soil parameters and soil $N$ pools}

During drought simulation, in total $358 \mathrm{~mm}$ of precipitation were excluded, equalling one-third of mean annual precipitation. This led to a significant decrease of SWC to $16.9 \%$ $( \pm 1.4 \%)$ at the meadow, and to $21.2 \%( \pm 3.5 \%)$ at the abandoned site (Table 1, Fig. 1). However, the initial $\mathrm{WHC}_{\max }$ was significantly lower at the meadow than at the abandoned site (Table 1), thus the amount of water remaining in meadow soils was lower during drought as compared to the abandoned site. At both sites, rewetting had no immediate effects on the SWC in drought-treated plots, but 7 weeks after the end of drought the SWC levels had approximated those of controls (Fig. 1).

At both sites drought had no significant effect on the $\mathrm{N}$ pools (Table 2, Fig. 2) when concentrations were calculated per gram dry soil, although the meadow was characterized by significantly lower EON and $\mathrm{NH}_{4}^{+}$, but higher $\mathrm{NO}_{3}^{-}$concentrations compared to the abandoned site (Table 1, Fig. 2). However, when $\mathrm{N}$ concentrations were calculated per g soil water after 5 weeks of drought, EON and $\mathrm{NH}_{4}^{+}$concentrations were significantly increased at both sites, and remained on a higher level until 1 day after rewetting (Table 1, Fig. 3). In particular at the meadow, drought induced fivefold increases of $\mathrm{NH}_{4}^{+}$concentrations, while at the abandoned site $\mathrm{NH}_{4}^{+}$concentrations at most tripled. In contrast, $\mathrm{NO}_{3}^{-}$concentrations in the soil solution were not affected by drought, but strongly increased 1 day after rewetting at the meadow, while at the abandoned site no clear effect of drought was detected (Table 1, Fig. 3). At both sites 7 weeks after the end of drought EOC and $\mathrm{NH}_{4}^{+}$concentrations were similar in drought and control plots - only in soils of the meadow were $\mathrm{NO}_{3}^{-}$concentrations in drought-treated soils significantly increased (Table 1, Fig. 3).

\subsection{Effects of drought on microbial $\mathbf{N}$ transformation rates}

Potential gross rates of microbial $\mathrm{N}$ mineralization and $\mathrm{NH}_{4}^{+}$ immobilization were similar at both sites (Table 1, Fig. 4). However, only at the meadow drought significantly increased potential gross $\mathrm{NH}_{4}^{+}$immobilization rates, which consequently decreased the mean residence time (MRT) of $\mathrm{NH}_{4}^{+}$ 

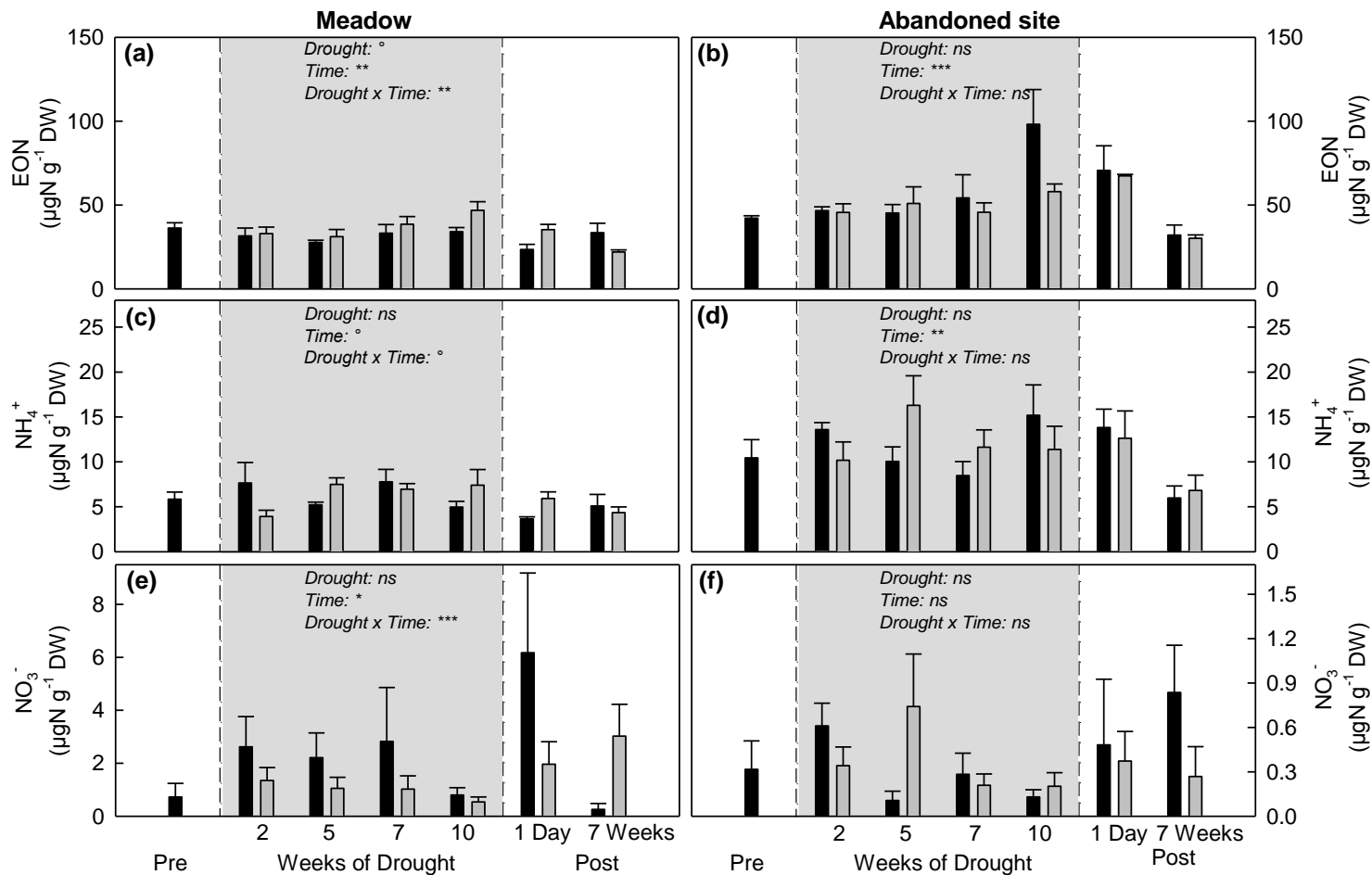

Figure 2. Soil $\mathrm{N}$ concentrations per $\mathrm{g}^{-1}$ dry soil over the course of the experiment at the meadow (left panels) and the abandoned site (right panels) in controls (black bars) and drought-treated plots (grey bars). (a, b) Extractable organic $\mathrm{N}(\mathrm{EON}),(\mathbf{c}, \mathbf{d})$ ammonium $\left(\mathrm{NH}_{4}^{+}\right)$and $(\mathbf{e}, \mathbf{f})$ nitrate $\left(\mathrm{NO}_{3}^{-}\right.$, note the different scaling!). The grey background indicates the period of drought treatment. Differences between control and drought at single sampling points were assessed by $t$-tests with Bonferroni-corrected levels of significance $(n=4$, respectively, bars show means; error bars indicate standard error). Effects of drought and sampling time were assessed by two-way repeated-measures ANOVA; for further details see Table 3 .

(perg dw) from $27.4 \pm 6.8 \mathrm{~h}$ to $14.4 \pm 1.3 \mathrm{~h}$. At the abandoned site, in contrast, potential gross $\mathrm{N}$ mineralization and immobilization, as well as the MRT of $\mathrm{NH}_{4}^{+}(50.8 \pm 10.5 \mathrm{~h})$ were not affected by drought (Table 3, Fig. 4). At neither site potential $\mathrm{N}$ mineralization, nor $\mathrm{NH}_{4}^{+}$immobilization responded to rewetting.

Potential gross rates of nitrification and microbial $\mathrm{NO}_{3}^{-}$ immobilization were significantly lower and the $\mathrm{NO}_{3}^{-}$pool turned over much slower $(30.3 \pm 9.9 \mathrm{~h})$ at the meadow than at the abandoned site $(2.2 \pm 0.7 \mathrm{~h}$ Table 1 , Supplement Fig. S1). At both sites potential nitrification and microbial $\mathrm{NO}_{3}^{-}$immobilization rates were influenced by sampling time, indicating a strong seasonal variability (Table 1, Fig. 4). At the meadow drought affected neither potential nitrification, nor potential $\mathrm{NO}_{3}^{-}$immobilization rates. At the abandoned site, in contrast, drought significantly altered both potential nitrification and $\mathrm{NO}_{3}^{-}$immobilization rates, which showed less variance compared to controls (Table 3, Fig. 4). One day after rewetting at both sites potential nitrification and $\mathrm{NO}_{3}^{-} \mathrm{im}-$ mobilization rates slightly increased in drought-treated plots, but seven weeks after rewetting, the rates were again similar to the controls (Fig. 4).

\subsection{Effects of drought on the abundance of ammonia-oxidizers}

The abundance of archaeal amoA genes (as a proxy for AOA) was similar at both sites, ranging from $8.1 \pm 10^{5}$ to $3.2 \pm 10^{6}$ copies $\mathrm{g}^{-1} \mathrm{DW}$ soil at the meadow and from $5.2 \pm 10^{5}$ to $3.7 \pm 10^{6}$ copies $\mathrm{g}^{-1} \mathrm{DW}$ soil at the abandoned site. At the meadow bacterial amoA gene copies (as a proxy for $\mathrm{AOB}$ ), ranging from $2.5 \pm 10^{5}$ to $1.7 \pm 10^{6}$ copies $^{-1} \mathrm{DW}$ soil, were as abundant as archaeal amoA gene copies, thus AOA : AOB ratios ranged between 1 and 10. At the abandoned site, in contrast, AOB numbers ranged from $8.0 \pm 10^{4}$ to $7.8 \pm 10^{5}$ copies $\mathrm{g}^{-1} \mathrm{DW}$ soil, which was significantly lower, consequently AOA: AOB ratios were significantly higher (ranging between 10 and 100) than at the meadow (Table 1, Fig. 5).

At the meadow drought significantly decreased archaeal amoA gene copy numbers, while the abundance of bacterial $a m o A$ remained unaffected, thus the ratio of $\mathrm{AOA}$ : $\mathrm{AOB}$ significantly decreased compared to the controls (Table 3 , Fig. 5). At the abandoned site, in contrast, drought affected neither AOA, nor AOB abundances. 
Table 3. Effects of the drought simulation and sampling time on all measured soil parameters and microbial abundances for the meadow and the abandoned site assessed by repeated-measures ANOVA $(n=28)$; within-factor was plot identity $(n=4)$; asterisks mark levels of significance ${ }^{\circ}=p<0.1 ;^{*}=p<0.05 ;^{* *}=p<0.01{ }^{* * *}=p<0.001$.

\begin{tabular}{|c|c|c|c|c|c|c|c|c|c|c|c|c|}
\hline & \multicolumn{6}{|c|}{ Meadow } & \multicolumn{6}{|c|}{ Abandoned site } \\
\hline & $F(1)$ & $p$ & $F(6)$ & $p$ & $F(1,6)$ & $p$ & $F(1)$ & $p$ & $F(6)$ & $p$ & $F(1,6)$ & $p$ \\
\hline $\mathrm{C}_{\text {tot }}$ & 3.3 & & 1.4 & & 1.0 & & 2.2 & & 3.8 & $* *$ & 2.1 & $\circ$ \\
\hline $\mathrm{N}_{\text {tot }}$ & 2.7 & & 1.3 & & 1.0 & & 1.8 & & 3.5 & $* *$ & 1.9 & $\circ$ \\
\hline$\delta^{15} \mathrm{~N}(\% \circ)$ bulk soil & 14.9 & $* * *$ & 3.6 & $* *$ & 1.8 & & $<0.1$ & & 2.8 & $*$ & 1.0 & \\
\hline EON & 2.9 & $\circ$ & 4.4 & $* *$ & 3.4 & $* *$ & 1.1 & & 11.3 & $* * *$ & 1.1 & \\
\hline $\mathrm{NH}_{4}^{+}$ & 0.4 & & 2.0 & $\circ$ & 2.3 & $\circ$ & $<0.1$ & & 4.0 & $* *$ & 1.3 & \\
\hline $\mathrm{NO}_{3}^{-}$ & 0.2 & & 2.8 & $*$ & 3.6 & $* *$ & 0.1 & & 0.6 & & 1.2 & \\
\hline $\mathrm{MRT}_{\mathrm{NH}_{4}}^{+}$ & 3.7 & $\circ$ & 1.4 & & 1.6 & & 1.8 & & 2.0 & & 2.8 & \\
\hline Gross N Min & 1.9 & & 3.6 & $* *$ & 1.2 & & $<0.1$ & & 2.8 & $*$ & 0.9 & \\
\hline Gross $\mathrm{NH}_{4}^{+}$Immo & 4.5 & $*$ & 2.8 & $*$ & 1.5 & & $<0.1$ & & 0.3 & & 0.5 & \\
\hline GrossNit & 0.1 & & 1.2 & & 0.6 & & 4.9 & $* * *$ & 3.6 & $\circ$ & 4.1 & $* *$ \\
\hline Gross $\mathrm{NO}_{3}^{-}$Immo & 1.1 & & 1.5 & & 3.3 & $* *$ & 7.5 & $* *$ & 8.6 & $* * *$ & 2.2 & $\circ$ \\
\hline $\mathrm{AOA}$ & 10.8 & $* *$ & 0.8 & & 0.7 & & 0.1 & & 1.1 & & 0.4 & \\
\hline $\mathrm{AOB}$ & 2.4 & & 1.6 & & 0.8 & & 0.1 & & 0.5 & & 1.2 & \\
\hline $\mathrm{AOA}: \mathrm{AOB}$ & 19.9 & $* * *$ & 1.1 & & 1.0 & & 2.5 & & 1.1 & & 0.4 & \\
\hline
\end{tabular}

\subsection{Drought effects in relation to site-specific differences}

To summarize and illustrate drought effects in relation to site-specific differences, a PCA was conducted, including all studied parameters. In total, three factors with eigenvalues $>1$ were identified and accounted for $68.9 \%$ of the total variance. In a biplot showing the first two factors (PC1 and $\mathrm{PC} 2$, accounting in total for $55.1 \%$ of the variance) on PC1 samples were separated (34.9\%) according to sampling site (two-way ANOVA with factor loadings: $(F(1)=102.4$; $p<0.001)$ and drought treatment $(F(1)=5.9 ; p<0.05$, interaction: ns). PC2 explained $20.1 \%$ and primarily displayed drought effects $(F(1)=9.1 ; p=<0.01)$, but was not affected by site $(F(1)=0.9 ; p=n s ;$ interaction: ns). The main parameters responsible for the separation along PC1 were higher $\mathrm{EON}$ and $\mathrm{NH}_{4}^{+}$concentrations, as well as higher potential gross nitrification and gross $\mathrm{NO}_{3}^{-}$immobilization rates at the abandoned site, which were in contrast to higher abundances of $\mathrm{AOB}$ and $\mathrm{NO}_{3}^{-}$concentrations that were dominating at the meadow (Fig. 6). This pattern was supported by positive correlations between $\mathrm{EON}$ and $\mathrm{NH}_{4}^{+}$concentrations in controls of both the meadow $(R=0.59, p<0.001)$ and the abandoned site $(R=0.57, p<0.01)$. Moreover, in controls of the meadow $\mathrm{NO}_{3}^{-}$correlated negatively with $\mathrm{EON}$ concentrations ( $R=-0.67, p<0.001)$, but positively with AOB abundances $(R=0.42, p<0.05)$. Only in controls of the abandoned site EON correlated with gross $\mathrm{N}$ mineralization $(R=0.60, p<0.001)$ and with $\operatorname{SWC}(R=0.60$, $p<0.001)$. PC2 separated the drought treatment from the controls, although this effect was stronger for the meadow than for the abandoned site. SWC was distributed along PC2 opposing the vectors for potential gross $\mathrm{N}$ mineralization and gross $\mathrm{NH}_{4}^{+}$immobilization (Fig. 6). Specifically in soil samples from the meadow subjected to drought the potential gross $\mathrm{NH}_{4}^{+}$immobilization rates correlated negatively with $\operatorname{SWC}(R=-0.62, p<0.001)$.

\section{Discussion}

\subsection{Effects of drought on soil $\mathbf{N}$ dynamics and ammonia-oxidizer abundances}

In our study the potential of the microbial community to mineralize organic nitrogen to ammonium was not affected by drought irrespective of site-specific differences related to land management. Thus, this comparably "broad" soil process remained stable and could show to indicate that $\mathrm{N}$ mineralization may have been dominated by drought-tolerant 

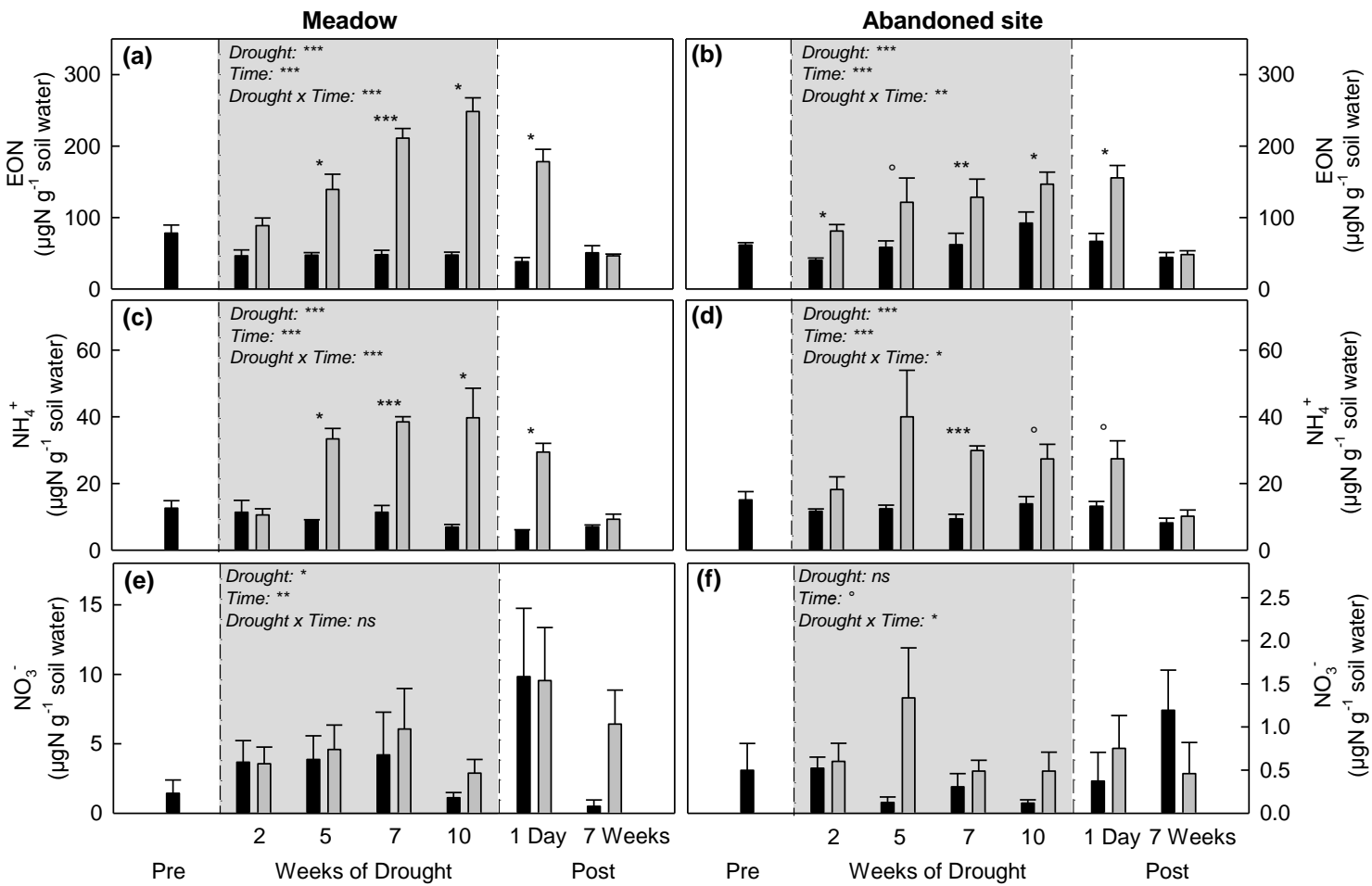

Figure 3. Soil $\mathrm{N}$ concentrations per $\mathrm{g}^{-1}$ soil water over the course of the experiment at the meadow (left panels) and the abandoned site (right panels) in controls (black bars) and drought-treated plots (grey bars). (a, b) Extractable organic $\mathrm{N}(\mathrm{EON}),(\mathbf{c}, \mathbf{d})$ ammonium $\left(\mathrm{NH}_{4}^{+}\right)$and $(\mathbf{e}, \mathbf{f})$ nitrate $\left(\mathrm{NO}_{3}^{-}\right.$, note the different scaling!). The grey background indicates the period of drought treatment. Differences between control and drought at single sampling points were assessed by $t$-tests with Bonferroni-corrected levels of significance; ${ }^{\circ} p<0.1 ;{ }^{*} p<0.05 ;{ }^{* *}$ $p<0.01,{ }^{* * *} p<0.001,(n=4$, respectively, bars show means; error bars indicate standard error). Effects of drought and sampling time were assessed by two-way repeated-measures ANOVA; for further details see Table 3.

microbial generalists like fungi (Allison and Martiny, 2008; Schimel and Schaeffer, 2012). Only in soils of the managed meadow did potential gross rates of microbial $\mathrm{NH}_{4}^{+}$immobilization and therefore $\mathrm{NH}_{4}^{+}$turnover increase during drought. This points to a potentially increased microbial $\mathrm{N}$ demand to facilitate the synthesis of nitrogenous osmolytes to balance the osmotic potential between the soil solution and microbial cells (Schimel et al., 2007). At the abandoned site, however, the microbial $\mathrm{NH}_{4}^{+}$uptake potential remained unaffected by drought, which suggests a high stability of this process, or a microbial community that might use other than N-containing substrates for osmolyte production (Schimel et al., 2007).

As microbial nitrification appears to be a more "narrow" process than microbial $\mathrm{N}$ mineralization (Schimel and Schaeffer, 2012), we expected nitrification rates to respond sensitively to dry conditions. In the presented study, however, responses of potential nitrification to drought were diverging between the studied sites. In accordance with other studies, where grassland and heathland sites had been subjected to drought (Hartmann et al., 2013; Larsen et al., 2011), the microbial nitrification potential was not affected by drought at the managed meadow. At the abandoned site, in turn, drought reduced the dynamics of potential nitrification and
$\mathrm{NO}_{3}^{-}$immobilization, which was also shown, e.g. for forest soils (Chen et al., 2011), or grassland under oak forest (Stark and Firestone, 1996). Thus, responses of potential nitrification rates to drought seem to be strongly context dependent and may not be generalized.

Drought distinctly affected bacterial and archaeal amoA gene copy numbers, which were used as proxy for the abundance of AOB and AOA. As expected, AOB were stable and not affected by drought at both sites. The observed decrease of AOA in response to drought at the managed meadow in our study was similar to results reported by Thion and Prosser (2014), where the observed decrease of archaeal amoA abundance during drought was likely related to strong increases of $\mathrm{NH}_{4}^{+}$during drought. In our study soil $\mathrm{NH}_{4}^{+}$concentrations calculated per gram dry soil were not affected during drought at either site, similar to the study of Hartmann et al. (2013) in subalpine grassland soils. When $\mathrm{NH}_{4}^{+}$concentrations were calculated perg soil water, however, fivefold increases at the meadow and up to threefold increases at the abandoned site were observed. Thus, it is likely that the stronger increase of $\mathrm{NH}_{4}^{+}$in the soil solution of the meadow could have induced the decrease of archaeal amoA genes. Thus, our findings corroborate that responses of archaeal 

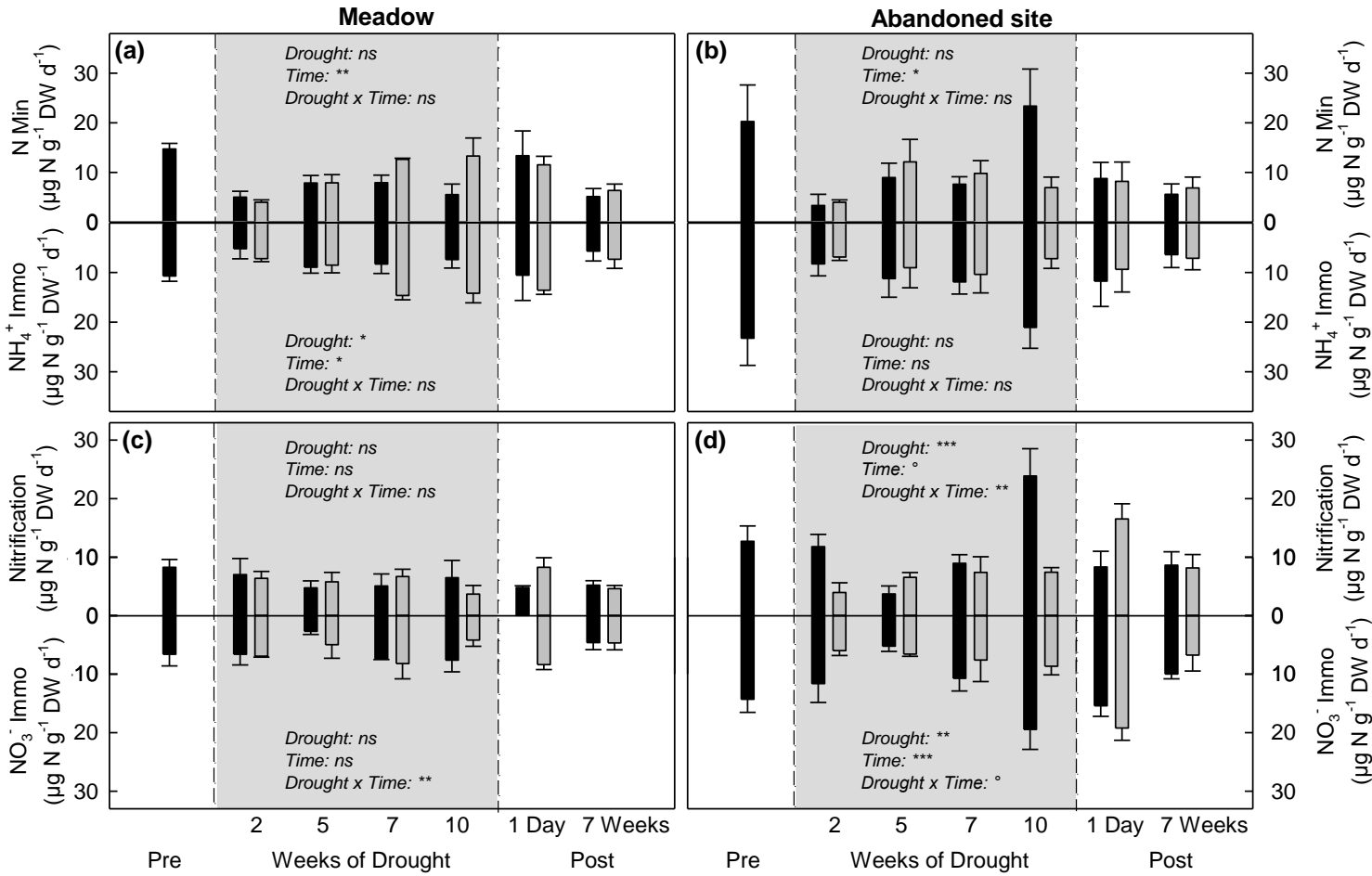

Figure 4. $\mathrm{N}$ transformation rates over the course of the experiment at the meadow (left panel) and the abandoned site (right panel) in control (black bars) and drought-treated plots (grey bars). (a, b) Gross $\mathrm{N}$ mineralization (upper part) and gross microbial $\mathrm{NH}_{4}^{+}$immobilization rates (lower part); (c, d) gross nitrification (upper part) and gross microbial $\mathrm{NO}_{3}^{-}$immobilization rates (lower part). The grey background indicates the period of drought treatment. Differences between control and drought-treated plots at single sampling points assessed by $t$ tests with Bonferroni-corrected levels of significance $(n=4$; error bars indicate standard error). Effects of drought and sampling time were assessed by two-way repeated-measures ANOVA; for further details see Table 3.

amoA abundances to drought could be driven by changes in soil $\mathrm{NH}_{4}^{+}$concentrations as a consequence of decreasing water content rather than by decreasing soil water content alone (Thion and Prosser, 2014; Delgado-Bazquerizo et al., 2013).

Overall, these findings partly support the hypothesis that the impact of drought on the abandoned site could be stronger at the meadow than at the abandoned site. In contrast to the managed meadow, where aboveground plant biomass is annually removed and harvested, at the abandoned site a thicker litter layer (Meyer et al., 2012), and higher SOM content were accumulated, which might have protected the soil from drying out (Brady and Weil, 2002; Franzluebbers, 2002; Knapp et al., 2008).

\subsection{Effects of rewetting and recovery dynamics}

Rewetting after drought has been shown to induce short-term increases of $\mathrm{N}$ mineralization in soil, which are likely caused by microbial release of accumulated osmolytes to avoid lysis, but also by re-connecting soil pores and increasing the nutrient availability for microbes (Evans and Wallenstein, 2012; Fierer and Schimel, 2002; Saetre and Stark, 2005). We therefore expected a strong increase of $\mathrm{N}$ mineralization rates in the soils after rewetting, but at both sites one day after rewet- ting neither gross $\mathrm{N}$ mineralization, nor $\mathrm{NH}_{4}^{+}$immobilization rates responded to water addition, which is similar to findings by Chen et al. (2011). Due to the described short-term character of $\mathrm{N}$ mineralization peaks after rewetting we might have missed a possible increase.

The potential rates of nitrification, as well as of $\mathrm{NO}_{3}^{-} \mathrm{im}-$ mobilization were increased at both sites one day after rewetting, while neither AOB, nor AOA gene copy numbers were affected. Placella and Firestone (2013) detected strong increases in the transcript abundances of both bacterial and archaeal amoA within two hours after rewetting at constant gene copy numbers, accompanied by increases in nitrification rates, which suggests an activity pulse of ammoniaoxidizing organisms (Fierer and Schimel, 2002). In nondrought-adapted grassland soils, however, $\mathrm{AOB}$ were found to have benefited from the flush of $\mathrm{NH}_{4}^{+}$after rewetting and to be more tolerant and resilient after drought than AOA (Thion and Prosser, 2014). Nonetheless, rewetting after long dry periods may initially rather stimulate microbial activity, and DNA-based methods could underestimate potential dynamics (Barnard et al., 2013).

In spite of the fact that effects of drought were very diverse and divergent between sites, 7 weeks after termination 

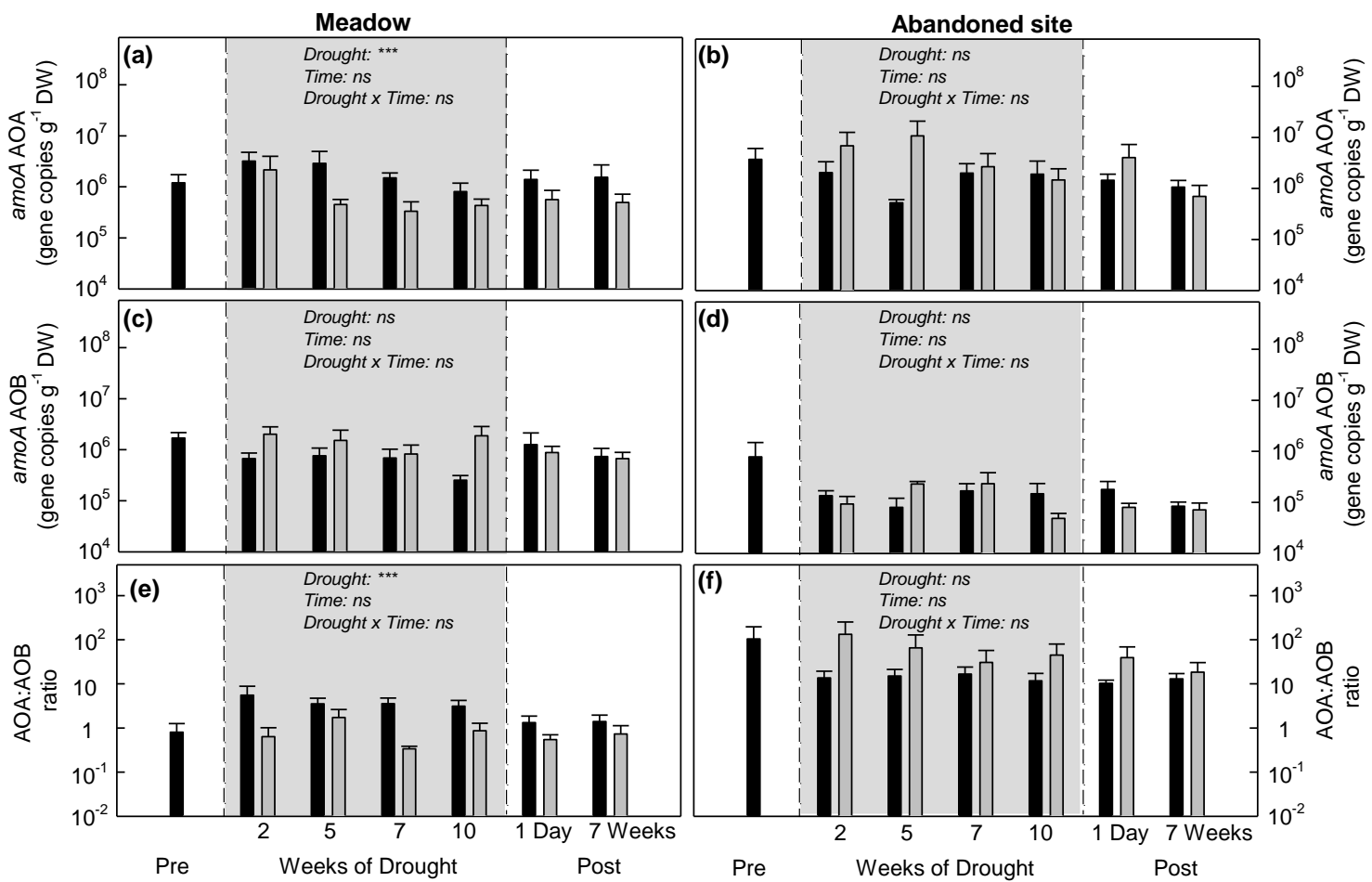

Figure 5. Gene copy numbers of ammonia-oxidizers at the meadow (left panel) and abandoned site (right panel) over the course of the experiment: (a, b) display archaeal (amoA AOA) and (c, d) bacterial (amoA AOB) amoA gene copy numbers, and (e, f) the ratio of AOA : AOB gene copy numbers. Black bars show controls, grey bars drought treatments ( $n=4$, error bars indicate standard error). The grey background indicates the period of drought treatment. Differences between control and drought-treated plots at single sampling points assessed by $t$ tests with Bonferroni-corrected levels of significance. Effects of drought and sampling time were assessed by two-way repeated-measures ANOVA; for further details see Table 3.

of drought all determined parameters, (except $\mathrm{NO}_{3}^{-}$concentrations at the meadow), were similar to undisturbed controls, which indicates a high resilience of the studied grasslands after drought. Moreover, we detected a strong temporal variability of organic and inorganic $\mathrm{N}$ concentrations in soils at both sites that might be related to overall seasonal microclimatic fluctuations, and indirectly to altered levels of plant $\mathrm{N}$ demand and plant phenology (see e.g. Kaiser et al., 2011).

\section{Summary and conclusions}

Our study showed that experimental drought under in situ conditions distinctly affected $\mathrm{N}$ cycling and gene abundances of ammonia-oxidizers in soils of differently managed mountain grassland sites. Potential $\mathrm{N}$ mineralization was less affected by drought than the nitrification potential. However, we could not detect a link between the potential nitrification rates and abundances of bacterial and archaeal ammoniaoxidizer, as was reported by Meyer et al. (2013) for intensively managed agricultural soils. This lack of correlation could indicate that the ammonia-oxidizers may not have fully exploited their nitrification potential (Prosser and Nicol, 2012). Alternatively, they may have down-regulated their transcriptional activity (Barnard et al., 2013; Placella et al., 2013) or heterotrophic nitrification by bacteria or fungi could have contributed to $\mathrm{NO}_{3}^{-}$production (e.g. Pedersen et al., 1990). It might also hint at functional and structural differences of AOA (Alves et al., 2013) and AOB populations between the studied sites (Gleeson et al., 2010).

The distinct responses of ammonia-oxidizer in the studied grasslands, specifically of AOA, could likely be related to increases of $\mathrm{NH}_{4}^{+}$in the soil solution rather than to decreases of soil water content per se, but our results only partially confirmed this idea. Generally, impacts of drought were more pronounced at the managed as compared to the abandoned grassland, which could have been caused by beneficial effects of a thicker litter layer and higher soil organic matter content on soil moisture at the abandoned grassland. In addition, differences found in the prevalent N-pools, nitrification rates, as well as abundances of ammonia-oxidizing organisms between the two grasslands, suggest that effects of drought on soil $\mathrm{N}$ dynamics could have been modulated by the level of land-use.

The Supplement related to this article is available online at doi:10.5194/bg-11-6003-2014-supplement. 


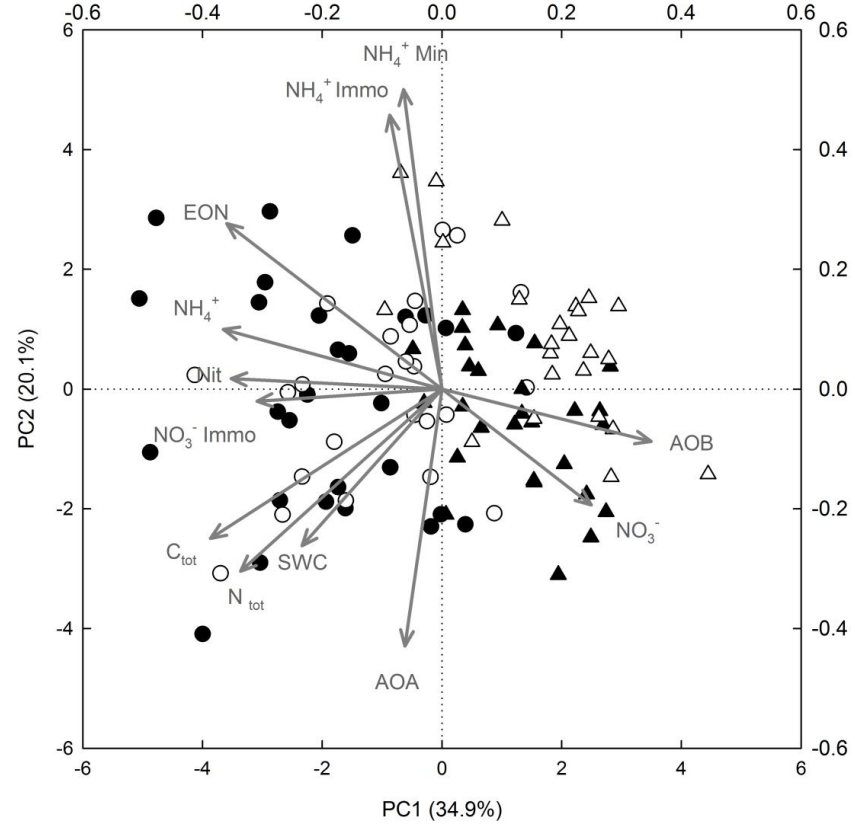

Figure 6. Biplot, displaying $\mathrm{PC} 1$ and $\mathrm{PC} 2$ derived from principal component analysis. Filled symbols represent control plots at the meadow (triangles) and the abandoned site (circles), open symbols show the drought treatment of the respective sites. Vectors display the variables contributing to PCA $\left(\mathrm{C}_{\text {tot }}=\right.$ total carbon, $\mathrm{N}_{\text {tot }}=$ total nitrogen; for further abbreviations see Sect. 3).

Acknowledgements. We thank Pavla Debeljak, Anna Knoltsch, Anna Teufl and Georg Weltin for their valuable assistance during sample processing, as well as MargareteWatzka for EA-IRMS measurements. Moreover, we want to thank the two anonymous referees for their valuable comments on the paper. This work was funded by the Austrian Science Foundation (FWF; P22214-B17). Ute Szukics was supported by "Nachwuchsförderung 2011 der Universität Innsbruck (no. 134753)" and by the TWF (Tiroler Wissenschaftsfonds, TWF UNI-0404/1121).

Edited by: P. van Bodegom

\section{References}

Allison, S. D. and Martiny, J. B. H.: Resistance, resilience, and redundancy in microbial communities, Proceedings of the national academy of sciences of the USA, 105, 11512-11519, 2008.

Alves, R., Wanek, W., Zappe, A., Richter, A., Svenning, M., Schleper, C., and Urich, T.: Nitrification rates in Arctic soils are associated with functionally distinct populations of ammoniaoxidizing archaea, The ISME J., 7, 1620-1631, 2013.

Auyeung, D. S. N., Suseela, V., and Dukes, J.: Warming and drought reduce temperature sensitivity of nitrogen transformations, Glob. Change Biol., 19, 662-676, 2013.

Bahn, M., Knapp, M., Garajova, Z., Pfahringer, N., and Cernusca, A.: Root respiration in temperate mountain grasslands differing in land use, Glob. Change Biol., 12, 995-1006, 2006.
Bahn, M., Rodeghiero, M., Anderson-Dunn, M., Dore, S., Gimeno, C., Drösler, M., Williams, W., Ammann, C., Berninger, F., Flechard, C., Jones, S., Blzarolo, M., Kumar ,S., Newesely, C., Priwitzer, T., Raschi, A., Siegwolf, R., Susiluoto, S., Tenhunen, J., Wohlfahrt G., and Cernusca A.: Soil respiration in European grasslands in relation to climate and assimilate supply, Ecosystems, 11, 1352-1367, 2008.

Barnard, R. L., Osborne, C. A., and Firestone, M. K.: Responses of soil bacterial and fungal communities to extreme desiccation and rewetting, The ISME Journal, 7, 2229-2241, The ISME J., 7, 2229-2241, 2013

Birch, H.: The effect of soil drying on humus decomposition and nitrogen availability, Plant Soil, 1, 9-31, 1958.

Booth, M., Stark, J., and Rastetter, E.: Controls on nitrogen cycling in terrestrial ecosystems: a synthetic analysis of literature data, Ecol. Monogr., 75, 139-157, 2005.

Brady, N. C. and Weil, R. R.: Elements of the Nature and Properties of Soils, Prentice Hall, 2009.

Brankatschk, R., Töwe, S., Kleineidam, K., Schloter, M., and Zeyer, J.: Abundances and potential activities of nitrogen cycling microbial communities along a chronosequence of a glacier forefield, The ISME J., 5, 1025-1037, 2010.

Chen, Y., Bogner, C., Borken, W., Stange, C., and Matzner, E.: Minor response of gross $\mathrm{N}$ turnover and $\mathrm{N}$ leaching to drying, rewetting and irrigation in the topsoil of a Norway spruce forest, Europ. J. Soil Sci., 62, 709-717, 2011.

Delgado-Baquerizo, M., Gallardo, A., Wallenstein, M. D., and Maestre, F. T.: Vascular plants mediate the effects of aridity and soil properties on ammonia-oxidizing bacteria and archaea, FEMS Microbio., 85, 273-282, 2013.

Di, H. J., Cameron, K. C., Shen, J. P., Winefield, C. S., O'Callaghan, M., Bowatte, S., and He, J. Z.: Nitrification driven by bacteria and not archaea in nitrogen-rich grassland soils, Nat. Geosci., 2, 621-624, 2009.

Di, H. J., Cameron, K. C., Shen, J. P., Winefield, C. S., O'Callaghan, M., Bowatte, S., and He J. Z.: Ammonia-oxidizing bacteria and archaea grow under contrasting soil nitrogen conditions, FEMS Microbiol., 72, 386-394, 2010.

Emmett, B., Beier, C., Estiarte, M., Tietema, A., Kristensen, H., Wiliams, D., Penuelas, J., Schmidt, I., and Sowerby, A.: The response of soil processes to climate change: results from manipulation studies of shrublands across an environmental gradient, Ecosystems, 7, 625-637, 2004.

Erguder, T. H., Boon, N., Wittebolle, L., Marzorati, M., and Verstraete, W.: Environmental factors shaping the ecological niches of ammonia-oxidizing archaea, FEMS Microbiol. Rev., 33, 855-869, 2009.

Evans, S. E. and Wallenstein, M. D.: Soil microbial community response to drying and rewetting stress: does historical precipitation regime matter?, Biogeochemistry, 109, 101-116,2012.

Fierer, N. and Schimel, J.: Effects of drying-rewetting frequency on soil carbon and nitrogen transformations, Soil Biol. Biochem., 34, 777-787 2002.

Franzluebbers, A. J.: Water infliltration and soil structure related to organic matter and its stratification with depth, Soil Till. Res., 66, 197-205, 2002.

Gleeson, D., Müller, C., Banerjee, S., Ma, W., Siciliano, S., and Murphy, D.: Response of ammonia oxidizing archaea and bacte- 
ria to changing water filled pore space, Soil Biol. Biochem., 42, 1888-1891, 2010.

Gobiet, A., Kotlarski, S., Beniston, M., Heinrich , G., Rajczak, J., and Stoffel M.: 21st century climate change in the European Alps - areview, Sci. Total Environ., 43, 1138-1151, 2014.

Hartman, A. A., Barnard, R. L., Marhan, S., and Niklaus, P. A.: Effects of drought and $\mathrm{N}$-fertilization on $\mathrm{N}$ cycling in two grassland soils, Oecologia, 171, 705-717, 2013.

IPCC 2007: Parry, M., Canziani, O., Palutikof, J., van der Linden, P., and Hanson, C.: Climate change 2007: impacts, adaptation and vulnerability, Contribution of Working Group II to the Fourth Assessment Report of the Intergovernmental Panel on Climate Change, Cambridge University Press, Cambridge, UK, 982 pp., 2007.

IPCC, 2012: Field, C., Barros, V., Stocker, T., Dahe, Q., Dokken, D., Ebi, K., Mastrandrea, M., Mach, K., Plattner, G., Allen, S., Tignor, M., and Midgley, P.: Managing the risks of extreme events and disasters to advance climate change adaptation, Special report of the Intergovernmental Panel on Clim. Change, Cambridge University Press, Cambridge, UK, and New York, NY, USA, 582 pp., 2012.

Jia, Z. and Conrad, R: Bacteria rather than Archaea dominate microbial ammonia oxidation in an agricultural soil, Environ. Microbiol., 11, 1658-1671, 2009.

Kaiser, C., Fuchslueger, L., Koranda, M., Gorfer, M., Stange, C., Kitzler, B., Rasche, F., Strauss, J., Sessitsch, A., ZechmeisterBoltenstern, S., and Richter, A.: Plants control the seasonal dynamics of microbial $\mathrm{N}$ cycling in a beech forest soil by belowground C allocation, Ecology, 9, 1036-1051, 2011.

Kandeler, E. and Gerber, H.: Short-term assay of soil urease activity using colorimetric determination of ammonium, Biol. Fertil. Soils, 6, 68-72, 1988.

Knapp, A. K., Fay, P. A., Blair, J. M., Collins, S. L., Smith, M. D., Carlisle, J. D., Harper, C. W., Danner, B. T., Lett, M. S., and McCarron, J. K.: Rainfall variability, carbon cycling, and plant species diversity in a mesic grassland, Science, 298, 2202-2205, 2002.

Knapp, A. K., Beier, C., Briske, D. D., Classen, A. T., Luo, Y., Reichstein, M., Smith, M. D., Smith, S. D., Bell, J. E., Fay, P. A., Heisler, J. L., Leavitt, S. W., Sherry, R., Smith, B., and Weng E.: Consequences of more extreme precipitation regimes for terrestrial ecosystems, BioScience 58, 811-821, 2008.

Könneke, M., Bernhard, A. E., de la Torre, J. R., Walker, C. B., Waterbury, J. B., and Stahl, D. A.: Isolation of an autotrophic ammonia-oxidizing marine archaeon, Lett. Nat., 437, 543-546, 2005.

Kowalchuk, G. and Stephen, J.: AOB: A Model for Molecular Microbial Ecology, Ann. Rev. Microbiol., 55, 485-529, 2001.

Larsen, K., Andresen, L., Beier, C., Jonasson, S., Albert, K., Ambus, P., Arndal, M., Carter, M., Christensen, S., Holmstrup, M., Ibrom, A., Kongstad, J., van der Linden, L., Maraldo, K., Michelsen, A., Mikkelsen, T., Pilegaard, K., Priemé, A., RoPoulsen, H., Schmidt, I. K., Selsted M. B., and Stevnbak, K.: Reduced $\mathrm{N}$ cycling in response to elevated $\mathrm{CO}_{2}$, warming, and drought in a Danish heathland: Synthesizing results of the CLIMAITE project after two years of treatments, Glob. Change Biol., 17, 1884-1899, 2011.
LeBauer, D. and Treseder, K. K.: Nitrogen limitation of net primary productivity in terrestrial ecosystems is globally distributed, Ecology, 89, 371-379, 2008

Leininger, S., Urich, T., Schloter, M., Schwark, L., Qi, J., Nicol, G., Prosser, J., Schuster, S., and Schleper, C.: Archaea predominate among ammonia-oxidizing prokaryotes in soils, Nature, 442, 806-809, 2006.

Martens-Habbena, W., Berube, P., Urakawa, H., Torre, J., and Stahl, D.: Ammonia oxidation kinetics determine niche separation of nitrifying Archaea and Bacteria, Nature, 461, 976-979, 2009.

Meyer, A., Focks, A., Radl, V., Keil, D., Welzl, G., Schöning, I., Boch, S., Marhan, S., Kandeler, E., and Schloter, M.: Different Land Use Intensities in Grassland Ecosystems Drive Ecology of Microbial Communities Involved in Nitrogen Turnover in Soil, H. Smidtedited by, PLoS ONE, 8, e73536, doi:10.1371/journal.pone.0073536, 2013.

Meyer, S., Leifeld, J., Bahn, M., and Fuhrer , J.: Free and protected soil organic carbon dynamics respond differently to abandonment of mountain grassland, Biogeosciences, 9, 853-965, doi:10.5194/bg-9-853-2012, 2012.

Moyano, F., Manzoni, S., and Chenu, C.: Responses of soil heterotrophic respiration to moisture availability: An exploration of processes and models, Soil Biol. Biochem., 59, 72-85, 2013.

Pedersen, H., Dunkin, K. A., and Firestone, M. K.: The relative importance of autotrophic and heterotrophic nitrification in a confier forest soil as measured by $15 \mathrm{~N}$ tracer and pool diution techniques, Biogeochemistry, 44, 135-150, 1999.

Placella, S. A. and Firestone, M.K.: Transcriptional response of nitrifying communities to wetting of dry soil, Appl. Environ. Microbiol., 79, 3294-3302, 2013.

Prosser, J. and Nicol, G.: Relative contributions of archaea and bacteria to aerobic ammonia oxidation in the environment, Environ Microbiol., 10, 2931-2941, 2008.

Prosser, J. I. and Nicol, G. W.: Archaeal and bacterial ammoniaoxidisers in soil: the quest for niche specialisation and differentiation, Trends Microbiol., 20, 523-531, 2012.

R Core Team R: A language and environment for statistical computing, R Foundation for Statistical Computing, Vienna, Austria, ISBN 3-900051-07-0, http://www.R-project.org/, 2012.

Roeßler, M. and Müller, V.: Osmoadaptation in bacteria and archaea: common principles and differences, Environ. Microbiol., 3, 743-754, 2001.

Rotthauwe, J. H., Witzel, K. P., and Liesack, W.: The ammonia monooxygenase structural gene amoA as a functional marker: molecular fine-scale analysis of natural ammonia-oxidizing populations, Appl. Environ. Microbiol., 63, 4704-4712, 1997.

Saetre, P. and Stark, J.: Microbial dynamics and carbon and nitrogen cycling following re-wetting of soils beneath two semi-arid plant species, Oecologia, 142, 247-260, 2005.

Schär, C., Vidale, P. L., Lüthi, D., Frei, C., Häberli, C., Liniger, M. A., and Appenzeller, C.: The role of increasing temperature variability in European sumer heatwaves, Nature 427, 332-336, 2004.

Schauss, K., Focks, A., Leininger, S., Kotzerke, A., Heuer, H., Thiele-Bruhn, S., Sharma, S., Wilke, B., Matthies, M., Smalla, K., Munch, J., Amelung, W., Kaupenjohann, M., Schloter, M., and Schleper, C.: Dynamics and functional relevance of ammonia-oxidizing archaea in two agricultural soils, Environ. Microbiol., 11, 446-456, 2009. 
Schimel, J. and Bennett, J.: Nitrogen mineralization: challenges of a changing paradigm, Ecology, 85, 591-602, 2004.

Schimel, J. and Schaeffer, S.: Microbial control over carbon cycling in soil, Front. Microbiol., 3, 1-11, 2012.

Schimel, J., Jackson, L., and Firestone, M.: Spatial and temporal effects on plant-microbial competition for inorganic nitrogen in a california annual grassland, Soil Biol. Biochem., 21, 1059-1066, 1989.

Schimel, J., Balser, T., and Wallenstein, M.: Microbial stressresponse physiology and its implications for ecosystem function, Ecology, 88, 1386-1394, 2007.

Schmitt, M., Bahn, M., Wohlfahrt, G., Tappeiner, U., and Cernusca, A.: Land use affects the net ecosystem $\mathrm{CO}_{2}$ exchange and its components in mountain grasslands, Biogeosciences, 7, 2297-2309, doi:10.5194/bg-7-2297-2010, 2010.

Seneviratne, S., Lüthi, D., Litschi, M., and Schär, C.: Land-atmosphere coupling and climate change in Europe, Nature, 443, 205-209, 2006.

Stark, J. and Firestone, M.: Mechanisms for soil moisture effects on activity of nitrifying bacteria., Appl. Environ. Microbiol., 61, 218-221, 1995.

Stark, J. and Firestone, M.: Kinetic characteristics of ammoniumoxidizer communities in a California oak woodland-annual grassland, Soil Biol. Biochem., 28, 1307-1317, 1996.
Thion, C. and Prosser , J. I.: Differential response of non-adapted ammonia oxidising archaea and bacteria to drying rewetting stress, FEMS Microbiol. Ecol., doi:10.1111/1574-6941.12395, 2014.

Töwe, S., Kleineidam, K., and Schloter, M.: Differences in amplification efficiency of standard curves in quantitative real-time PCR assays and consequences for gene quantification in environmental samples, J. Microbiol. Methods, 82, 338-341, 2010.

Treusch A. H., Leininger S., Kletzin, A., Schuster, S. C., Klenk, H., and Schleper, C.: Novel genes for nitrite reductase and Amorelated proteins indicate a role of uncultivated mesophilic crenarchaeota in nitrogen cycling, Environ. Microbiol., 7, 1985-1995, 2005.

Verhamme, D. T., Prosser J. I., and Nicol G. W.: Ammonia concentration determines differential growth of ammonia-oxidising archaea and bacteria in soil microcosms, The ISME J., 5, 1067-1071, 2011.

Wanek, W., Mooshammer, M., Blöchl, A., Hanreich, A., and Richter, A.: Determination of gross rates of amino acid production and immobilization in decomposing leaf litter by a novel $15 \mathrm{~N}$ isotope pool dilution technique, Soil Biol. Biochem., 42, 1293-1302, 2010. 